\title{
Reporting on the recapture of electronic tagged fish by fishers in the Xingu River, Brazilian Amazon
}

\author{
Hahn, L. ${ }^{a *}$, Nunes, LD. ${ }^{a}$, Câmara, LF. ${ }^{a}$, Machado, LS. ${ }^{a}$, Abolis, D. ${ }^{a}$, Fries, LCC. ${ }^{a}$, \\ Martins, EG. ${ }^{b}$ and Garrone-Neto, D. ${ }^{c}$

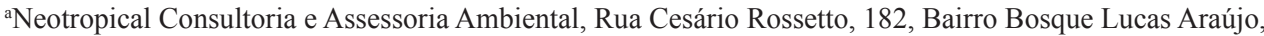 \\ CEP 99074-210, Passo Fundo, RS, Brazil \\ ${ }^{b}$ Department of Forest and Conservation Sciences, Centre for Applied Conservation Research, University of British \\ Columbia - UBC, Vancouver, BC, V6T 1Z4, Canada \\ 'College of Fishery Engineering, Universidade Estadual Paulista “Júlio de Mesquita Filho" - UNESP, Rua Nelson Brihi \\ Badur, 430, CEP 11900-000, Registro, SP, Brazil \\ *e-mail: lisiane@neotropical.com.br
}

Received: May 23, 2014 - Accepted: July 14, 2014 - Distributed: August 31, 2015

\begin{abstract}
Historically, studies on movements of migratory fishes in the Amazon basin using conventional and electronic tags were not feasible due to high costs and the challenges of tracking or recapturing fish in such a large area (reviewed in Val and Almeida-Val, 1995). Godoy (1979) was the first to attempt using mark-recapture techniques to study the movements of a migratory fish, focusing on movements of piramutaba (Brachyplatystoma vaillantii, Valenciennes, 1840) in the Amazon estuary. However, the study was conducted on a small spatial scale and it was not successful, with recapture rates below 1\% (Godoy, 1979). Decades later, Barthem and Goulding (1997) conducted extensive analyses of fishery catches data to investigate the migrations of the giant catfish (Brachyplatystoma spp.) in the Amazon. The findings suggested the use of large extensions of rivers and floodplains (over $3000 \mathrm{~km}$ ) by dourada (Brachyplatystoma rousseauxii, Castelnau, 1855) and piramutaba (Brachyplatystoma vailantii) to complete their lifecycle (Barthem and Goulding, 1997; Ruffino et al., 2000; Harvey and Carolsfeld, 2003). However, since the pioneering studies of Barthem and Goulding (1997), the movement ecology of migratory species in the Amazon River and its major tributaries (e.g. Madeira, Purus, Xingu, and Tapajós Rivers) remain largely unknown. Acknowledging the need for such information, three large hydropower projects in the Madeira (Santo Antônio and Jirau Dams) and Xingu Rivers (Belo Monte Dam) commissioned biotelemetry studies on the movement ecology of migratory species.

A large-scale study on migratory fishes using cuttingedge biotelemetry technology (first in South America using CARTs: Combined Acoustic and Radio Transmitters) has recently been initiated in the Xingu River along the area that will be affected by the Belo Monte Dam. The project is entitled "Movement and habitat use by migratory fishes in the Xingu River revealed by biotelemetry", and its main objectives are: i) to identify and describe the movements of migratory fish between downstream and upstream stretches of the Big Bend (locally known as "Volta Grande do Xingu"), before and after dam construction; ii) to
\end{abstract}

determine the timing and seasonality of these movements; and iii) to determine the maximum distances traveled by migratory fishes. A critical component of this project is the participation of fishers through the reporting of recaptured fish. Such reporting provides additional information about tagged fish movements and their condition several days to months after release. This note describes the recapture and reporting of electronic tagged fish in the Xingu River and discusses the role of fishers in providing information about fish migration in this large river system.

Fieldwork was conducted between February 2013 and February 2014, in the middle and lower Xingu River, Brazilian Amazon. Individuals of Brachyplatystoma filamentosum (Lichtenstein, 1819; piraíba/filhote, $\mathrm{n}=10$ ), Phractocephalus hemioliopterus (Bloch and Schneider, 1801; pirarara, n=121), Pseudoplatystoma punctifer (Castelnau, 1855; surubim, $\mathrm{n}=62$ ), Prochilodus nigricans (Agassiz, 1829; curimatá, $\mathrm{n}=153$ ), and Myleus rhomboidalis (Cuvier, 1818; pacú-de-seringa, $\mathrm{n}=55$ ) were captured using gill nets and longline fishing. Fish were anesthetised by immersion in clove oil, and internally (Wagner et al., 2011) or externally tagged with coded combined acoustic and radio transmitters (Lotek Wireless CART Series ${ }^{\circledR}$, models MM-MC-16-50 and MM-MC-16-33), depending on their size and body shape. In addition to the transmitters, fish $(n=214)$ captured from October 2013 to February 2014 were also marked with hydrostatic anchor tags (Hallprint ${ }^{\circ}$, model standard TBA) to facilitate identification and return of transmitters and/or tagged fish recaptured by fishers. Fish were weighed, measured, sexed, photographed, and then released at the same or near the capture sites. Permits to capture and tag fish were issued by the Instituto Brasileiro do Meio Ambiente e dos Recursos Naturais Renováveis (Permit N.145/2012).

Local media (radio, television, newspapers) and brochures were used to promote the report of the fishers on fish recaptures and return of transmitters (starting in February 2013 and ongoing). Fishers that reported on recaptured fish were rewarded with souvenirs and certificates 
Table 1. Tagged and recaptured fish information.

\begin{tabular}{|c|c|c|c|c|c|}
\hline Species & Release date & Recapture date & $\begin{array}{c}\text { Days after } \\
\text { release }\end{array}$ & $\begin{array}{c}\text { Distance }(\mathrm{km}) \\
\text { from release } \\
\text { site } \\
\end{array}$ & $\begin{array}{c}\text { Upstream/ } \\
\text { Downstream } \\
\text { release site }\end{array}$ \\
\hline P. hemioliopterus & $11 / 13 / 13$ & $11 / 28 / 13$ & 15 & 5 & Upstream \\
\hline P. hemioliopterus & $2 / 22 / 13$ & $3 / 31 / 13$ & 37 & 0 & RS \\
\hline P. hemioliopterus & $11 / 21 / 13$ & $1 / 19 / 14$ & 59 & 1 & RS \\
\hline P. hemioliopterus & $10 / 28 / 13$ & $12 / 31 / 13$ & 64 & 0 & RS \\
\hline P. hemioliopterus & $11 / 21 / 13$ & $1 / 31 / 14$ & 71 & 0 & RS \\
\hline P. hemioliopterus & $2 / 20 / 13$ & $6 / 30 / 13$ & 130 & 0 & RS \\
\hline P. hemioliopterus & $2 / 19 / 13$ & $8 / 13 / 13$ & 175 & 0 & RS \\
\hline P. nigricans & $3 / 20 / 13$ & $3 / 31 / 13$ & 11 & 0 & RS \\
\hline P. nigricans & $1 / 14 / 14$ & $1 / 31 / 14$ & 17 & 1 & RS \\
\hline P. punctifer & $2 / 12 / 14$ & $4 / 24 / 14$ & 71 & 8 & Downstream \\
\hline P. punctifer & $11 / 18 / 13$ & $2 / 15 / 14$ & 89 & 160 & Upstream \\
\hline P. punctifer & $2 / 22 / 13$ & $2 / 28 / 14$ & 371 & 73 & Upstream \\
\hline
\end{tabular}

$\mathrm{RS}=\leq 1 \mathrm{~km}$ from release site.

for their contribution to the study and the conservation of migratory fish in the Xingu River.

As of April 2014 (15 months after fish tagging started), 12 fish (curimatá $=2$, pirarara $=7$, and surubim $=3 ; 3 \%$ of total tags) were recaptured and reported by fishers in the Xingu River (Table 1). Most of the fish $(n=10)$ were recaptured at distances $\leq 8 \mathrm{~km}$ from the release site, whereas two surubim were recaptured, 73 and $160 \mathrm{~km}$ upstream of the release site. Recaptures occurred between 11 and 371 days after release.

All recaptured fish had been internally tagged with the transmitters. Information about the condition of the incision site was provided for three $(25 \%$, all pirarara) of the recaptured fish. According to fishers, the incision site was completely healed and sutures were not present (for the pirarara recaptured, 59 and 64 days after release) or the incision site was healed but sutures were still present (for the pirarara recaptured, 15 days after release).

Seven out of 12 recaptured fish had anchor tags attached to the base of the dorsal fin. According to fishers, two pirarara were released back to the river after visualisation of the anchor tags and recording of the tag number. Indeed, the use of anchor tags makes it easier to identify fish carrying transmitters, increasing the chances of returning tagged fish alive to the river and reporting of the recapture.

Data about recapture of electronic tagged fish and return of transmitters by fishers has been reported in other biotelemetry projects in Brazil and ranged from 13 to $54 \%$ (Godinho and Kynard, 2006; Godinho et al., 2007; Hahn et al., 2011; Pesoa and Schulz, 2010), values that are greater than observed so far in the Xingu River. The return of transmitters is important because it not only makes it possible to reuse the tags in other fish, but also because fishers will provide information on the use of habitats beyond the limits of study area and after the transmitter battery runs out. In the Uruguay River a tagged dourado (Salminus brasiliensis; Cuvier, 1818) was recaptured $300 \mathrm{~km}$ downstream of the study area after the monitoring was over (Hahn et al., 2011). In the Madeira River, a radio tagged dourada was recaptured by a fisher $150 \mathrm{~km}$ downstream of the study area (L. Hahn, personal observation).

The collaboration of Xingu River fishers has been very important up to this phase of the biotelemetry project to understand the effects of handling and tagging on post-release healing and survival. In the near future, recaptures might also help to elucidate the movements outside the study area, as identified in other projects in Brazil, and the reproductive condition of recaptured fish (potentially helping to identify reproductive migrations). Coupling high-tech tracking tools with recapture information will generate important results that may prove useful for the future management of migratory fishes in the Xingu River.

\section{Acknowledgements}

The fieldwork would not have been possible without the exceptional collaboration of Rogério R. Silva, Silvestre S. Pessoa, Jayson B. Huss, Lucas V. Garcia and Mitchell M. Sisak. The Norte Energia S. A. and the Tractebel Engineering/ Leme Engenharia teams, especially Raimundo L. Reis, Sandro T. Emoto and Luís A. S. Vasconsellos, provided logistic support and access to the study sites. Professional fishers and riverine people kindly responded the request to provide information on the recapture of tagged fish. This project is funded by Norte Energia.

\section{References}

BARTHEM, R. and GOULDING, M., 1997. The catfish connection: ecology, migration, and conservation of Amazon predators. New York: Columbia University Press. 144 p.

GODINHO, AL. and KYNARD, B., 2006. Migration and spawning of Radio-Tagged Zulega Prochilodus argenteus in a dammed 
Brazilian River. Transactions of the American Fisheries Society, vol. 135, no. 3, p. 811-824. http://dx.doi.org/10.1577/T04-176.1.

GODINHO, AL., KYNARD, B. and GODINHO, H., 2007. Migration and Spawning of female surubim (Pseudoplatystoma corruscans, Pimelodidae) in the São Francisco River, Brazil. Environmental Biology of Fishes, vol. 80, no. 4, p. 421-433. http://dx.doi.org/10.1007/s10641-006-9141-1.

GODOY, MP., 1979. Marcação e migração da piramutaba Brachyplatystoma vaillantii (Val., 1840) na bacia amazônica (Pará e Amazonas, Brasil) (Pisces, Nematognathi, Pimelodidae). Boletim da FCAP, vol. 11, p. 3-21.

HAHN, L., AGOSTINHO, AA., ENGLISH, KK., CAROSFELD, J., CÂMARA, LF. and COOKE, SJ., 2011. Use of radiotelemetry to track threatened dorados Salminus brasiliensis in the upper Uruguay River, Brazil. Endangered Species Research, vol. 15, no. 2, p. 103-114. http://dx.doi.org/10.3354/esr00363.

HARVEY, B. and CAROLSFELD, J., 2003. Fishes of the floods. In CAROSFELD, J., HARVEY, B., ROSS, C. and BAER, A. (Eds.). Migratory fishes of South America: biology, fisheries and conservation status. Victoria: World Fisheries Trust/World Bank/IDRC. p. 3-11.
PESOA, NA. and SCHULZ, UH., 2010. Diel and seasonal movements of grumatã Prochilodus lineatus (Valenciennes 1836) (Characiformes: Prochilodontidae) in the Sinos River, Southern Brazil. Brazilian Journal of Biology, vol. 70, no. 4, supplement, p. 1169-1177. http://dx.doi.org/10.1590/S1519-69842010000600006. PMid:21225158.

RUFFINO, ML., BARTHEM, RB. and FISCHER, CFA., 2000. Perspectivas do manejo dos bagres migradores na Amazônia. In Instituto Brasileiro do Meio Ambiente e dos Recursos Naturais Renováveis - IBAMA. (Org.). Recursos pesqueiros do Médio Amazonas: biologia e estatística pesqueira. Brasília: IBAMA. vol. 22, p. 141-152.

VAL, AL. and ALMEIDA-VAL, VMF., 1995. Fishes of the Amazon and their environment. Berlin: Springer-Verlag. 224 p. http://dx.doi.org/10.1007/978-3-642-79229-8.

WAGNER, GF., COOKE, SJ., BROWN, RS. and DETERS, KA., 2011. Surgical implantation techniques for electronic tags in fish. Reviews in Fish Biology and Fisheries, vol. 21, no. 1, p. 71-81. http://dx.doi.org/10.1007/s11160-010-9191-5. 